\title{
Pengaruh profitabilitas, struktur aktiva, dan likuiditas terhadap struktur modal pada perusahaan makanan minuman yang terdaftar di Bursa Efek Indonesia pada tahun 2014-2017
}

\section{Yona Putri Nabayu*; Novelia Marbun ;Hannitra Fitria Ginting ;Novi Adriyani Sebayang ; Tetty Tiurma Uli Sipahutar}

\author{
Prodi Akuntansi, Fakultas Ekonomi, Universitas Prima Indonesia \\ *E-mail korespodensi: Yonaputri10@gmail.com
}

\begin{abstract}
The purpose of conducting this research is to examine the effect of profitability, asset structure, liquidity, on the capital structure of food and beverage companies listed on the Indonesia Stock Exchange in 2014-2017. This study used a sample of 36 food and beverage companies listed on the Indonesia Stock Exchange in 2014-2017. The approach method used in this research is quantitative, the type of research used is descriptive quantitative, the nature of this research is causal and the type of secondary data. Multiple linear regression is used in the data analysis method. Judging from the results of this study that profitability partially does not affect capital structure while asset structure partially has a negative and significant effect on capital structure and liquidity has a positive and significant effect on capital structure. Simultaneously, profitability, asset structure, liquidity have a positive and significant impact on capital structure. The results of the coefficient and determination test obtained an adjusted R Square value of 0.252 or $25.2 \%$, this means that the dependent variable, namely the capital structure can be explained by variations of the four independent variables, namely profitability, asset structure and liquidity by $25.2 \%$, while the remaining $74.8 \%$ is explained by other variables not included in this study.
\end{abstract}

Keywords: Return on Asset,Fixed assed,Current ratio,Debt to equity

\begin{abstract}
Abstrak
Tujuan melakukan penelitian ini adalah untuk menguji pengaruh profitabilitas, struktur aktiva, likuiditas, terhadap struktur modal perusahaan makanan dan minuman yang terdaftar di Bursa Efek Indonesia pada 2014-2017. Penelitian ini menggunakan sampel 36 perusahaan makanan dan minuman yang terdaftar di Bursa Efek Indonesia pada 20142017. Metode pendekatan yang digunakan dalam penelitian ini adalah kuantitatif, jenis penelitian yang digunakan adalah deskriptif kuantitatif, sifat penelitian ini adalah kausal dan jenis data sekunder. Regresi linier berganda digunakan dalam metode analisis data. Dilihat dari hasil penelitian ini bahwa profitabilitas, secara parsial tidak berpengaruh terhadap struktur modal sedangkan struktur aktiva, secara parsial berpengaruh negatif dan signifikan terhadap struktur modal dan likuiditas memiliki pengaruh positif dan signifikan terhadap struktur modal. Secara simultan profitabilitas, struktur aktiva, likuiditas memiliki pengaruh positif dan signifikan terhadap struktur modal. Hasil uji koefisien dan determinasi diperoleh nilai adjusted $\mathrm{R}$ Square sebesar 0,252 atau sebesar $25,2 \%$, ini berarti bahwa variabel dependen yaitu struktur modal dapat dijelaskan oleh variasi dari empat variabel independen, yaitu profitabilitas, struktur aktiva dan likuiditas sebesar $25,2 \%$, sedangkan sisanya sebesar 74,8\% dijelaskan oleh variabel lain yang tidak terdapat dalam penelitian ini.
\end{abstract}

Kata kunci: Profitabilitas, Struktur aktiva, Likiuiditas, Struktur modal. 


\section{PENDAHULUAN}

Ketatnya persaingan bisinis sekarang ini, membuat kesulitan pebisnis untuk mengembangkan usahanya dengan cepat. Kompetisi ini bisa mendorong perusahaan untuk berusah jadi yang paling baik. Didirikannya perusahaan dengan tujuan untuk mencapai harapan yakni mendapatkan laba yang besar dan bisa kompetitif dengan perusahaan dari dalam atau luar negeri.

Bursa Efek Indonesia saat ini mengalami pertumbuhan yang besar,pernyataan ini dapat terlihat dari banyaknya perusahaan go public, salah satunya adalah perusahaan industri manufaktur.Perusahann industri manufaktur terbagi menjadi beberapa perusahaan, salah satunya perusahaan industri makanan dan minuman. Industri ini mempunyai posisi yang sangat baik di Indonesia. Perusahaan makanan dan minuman sangat diminati oleh investor karena perusahaan tersebut merupakan perusahaan yang mampu berdiri dengan kondisi ekonomi di Indonesia. Juga, prospek perusahaan makanan dan minuman sangat baik pada hakikatnya. Segala komunitas memerlukan makanan dan minuman di kehidupan sehari-hari mereka.

Setiap perusahaan akan mendapatkan dana untuk memenuhi kebutuhan produknya. Profitabilitas tujuan utama bagi perusahaan dalam meningkatkan perkembangan kualitas perusahaan. Semakin tinggi profit yang diperoleh setiap tahun berarti perusahaan memiliki kualitas yang baik. Sebaliknya, semakin rendah profit yang diperoleh setiap tahun berarti perusahaan memiliki kualitas yang kurang baik. Dengan itu, maka investor akan menilai positif perusahaan tersebut.

Struktur aktiva suatu perusahaan memiliki pondasi yang besar pada perusahaan dalam menggunakan aktiva yang dimilikinya sebagai jaminan pembayaran hutang. Modal terbesar dalam perusahaan manufaktur biasanya dalam aktiva tetap seperti tanah bangunan sebagai jaminan hutang. Perusahaan yang struktur aktivanya sebagian besar dalam bentuk aktiva tetap akan menggunakan hutang jangka panjang dalam pemenuhan dana mereka.

Likuiditas sangat diperlukan perusahaan guna mengetahui kemampuan sebuah yang bersangkutan dalam membayarkan utang jangka pendeknya. Perusahaan yang dinilai positif di mata kreditur, apabila tingkat likuiditas perusahaan tersebut besar. Perusahaan yang tingkat likuiditasnya tinggi cenderung lebih mudah memperoleh permodalan melalui hutang.

Pada saat struktur modal perusahaan tidak stabil dimana proporsi hutang yang berfluktuasi. Setiap perusahaan diperbolehkan mendapatkan pinjaman, sebagai modal untuk membiayai kebutuhan perusahaan. Namun, penggunaan utang tetap dalam posisi aman, yaitu sekitar $40 \%$ dari total nilai aset perusahaan. Jika utang perusahaan melebihi dari total nilai aset perusahaan sehingga akan mengalami kerugian.

Pada PT.Mayora Indah Tbk (MYOR), Pada tahun 2014 dengan keuntungan bersih senilai Rp.409.618.689.484 dan memperoleh total aset sebesar Rp 10.297.997.020.540. Pada tahun 2015 jumlah rata-rata laba bersih mengalami kenaikan sebesar 32,76\% dimana rata-rata laba bersih $\mathrm{Rp}$ 1.250.233.128.560. Dan kenaikan jumlah rata-rata laba bersih ini diikuti dengan kenaikan total aset sebesar 90,78\% dimana total aset menjadi Rp 11.342.715.686.221.

Pada PT. Nippon Indosari Corporindo Tbk (ROTI), pada tahun 2014 memiliki aktiva tetap senilai Rp. 420.318.388.535 dan memperoleh total aktiva sebesar Rp 2.142.894.276.216. Pada tahun 2015 jumlah rata-rata akiva tetap mengalami kenaikan sebesar 51,70\% dimana total aktiva tetap menjadi Rp 812.990.646.097. Dan kenaikan 
jumlah rata- rata aktiva tetap ini diikuti dengan kenaikan total aktiva sebesar $79,18 \%$ dimana total aktiva menjadi Rp 2.706.323.637.034.

Pada PT. Sekar Bumi Tbk (SKBM), pada tahun 2014 memiliki aktiva lancar sebesar Rp 379.596.707.512 dan memperoleh hutang lancar Rp 256.924.179.534. Pada tahun 2015 jumlah rata-rata aktiva lancar mengalami penurunan sebesar $111,04 \%$ dimana total aktiva lancar menjadi Rp 341.723.784.839. Dan penurunan aktiva lancar ini diikuti dengan kenaikan total hutang lancar sebesar $86,09 \%$ dimana total hutang lancar menjadi Rp 298.417.379.502.

Berdasar paparan terkait, penulis bermaksud meneliti yang judulnya: "Pengaruh Profitabilitas, Struktur Aktiva, Likuiditas Terhadap Struktur Modal pada Perusahaan Makanan dan Minuman Yang Terdaftar di Bursa Efek Indonesia Periode 2014-2017".

\section{TINJAUAN PUSTAKA}

\section{Pengaruh profitabilitas terhadap struktur modal}

Menurut Fahmi (2014:111), menganalisis struktur modal dianggap penting karena mampu menilai resiko jangka panjang dan tingkat pendapatan dalam perusahaan saat menjalankan aktivitasnya.

Menurut Infantri dan Suwitho (2015:4), semua perusahaan harus berusaha meningkatkan profitabilitasnya karena jika tingkat profitabilitasnya tinggi dan kegiatan bisnisnya berkembang maka perusahaan akan terjamin.

Menurut Mulyawan (2015:247), perusahaan yang profitabilitasnya tinggi maka tingkat utangnya pun cenderung rendah. Hal ini bisa dilihat dari pecking order theory yang menunjukkan bahwa perusahaan yang profitabilitasnya tinggi memiliki sumber dana internal yang banyak.

\section{Pengaruh struktur aktiva terhadap struktur modal}

Pendapat Weston dan Copeland (2010:175), jika perusahaan memiliki sejumlah besar aktiva tetap, sehingga perusahaan akan menggunakan banyak hutang berjangka panjang dengan tujuan bahwa aset ini bisa dipakai untuk membayar klaim. Jadi untuk kreditor, kepemilikan aktiva di perusahaan menunjukkan kualitas dimana aktiva adalah jaminan pembalikan utang. Sebagian besar penjelasan struktur modal menjelaskan bahwa perusahaan yang memiliki jenis aktiva akan mempengaruhi pilihan struktur modal. Nilai likuidasi perusahaan dapat juga dipertahankan oleh kepemilikan aktiva sehingga pemberi pinjaman terdorong untuk memberikan pinjamannya terhadap perbandingan aktiva yang lebih besar dan perusahaan akan memiliki tingkat pinjaman yang tinggi.

Menurut Sudana (2011:163), Perusahaan dengan kualitas aktiva lancar melebihi aktiva tetap terhadap total aktiva, maka bisa memanfaatkan hutang lebih besar agar menandai investasi yang mereka bandingkan dengan perusahaan yang kualitas aktiva tetap yang melebihi dari aktiva lancarnya.

Berdasarkan pendapat dari Kamaludin dan Rini (2012:325), Perusahaan dengan skala aktiva tetap yang besar bisa dipergunakan untuk jaminan untuk menggunakn utang dalam jumlah besar, maka memudahkan memperoleh akses ke permodalannnya.

\section{Pengaruh likuiditas terhadap struktur modal}

Pendapat Hery (2013:34), Hubungan likuiditas dengan struktur modal adalah 
likuiditas tidak hanya digunakan untuk membayar dividen saja tetapi juga dialokasikan untuk pembiayaan operasional, melunasi hutang yang telah jatuh tempo dan membeli aset tetap atau belanja modal untuk mengambil keuntungan dari peluang investasi yang ada. Tingginya tingkat likuiditas yang dimiliki perusahaan tidak berarti bahwa tingkat likuiditas tersebut hanya digunakan untuk membayar dividen, tetapi juga dipengaruhi oleh keputusan dalam investasi dan pembiayaan lain.

Menurut Van Horne dan John (2012:167), jika rasio saat ini semakin tinggi, maka sangat besar kecenderungan perusahaan untuk membayarkan kewajibannya; namun, perusahaan harus menganggap rasio ini sebagai ukuran kasar karena likuiditas tidak diperhitungkan oleh masing-masing komponen aset lancar.

Menurut Kasmir (2012:129), hubungan likuiditas dengan struktur modal adalah penyebab utama dari kurangnya dan ketidakmampuan perusahaan dalam membayar utangnya karena disebabkan oleh manajemen perusahaan atas kecerobohan dalam menjalankan bisnis. Dan alasan lainnya adalah bahwa manajemen perusahaan tidak memperhitungkan rasio keuangan yang disediakan maka tidak tahu yakni keadaan aktual perusahaan tidak lagi mampu dikarenakan besarnya utang melebihi aset lancar. Jika perusahaan telah melakukan analisis rasio yang terkait dengan ini, perusahaan bisa dengan mudahnya mengetahui keadaan dan posisi aktual perusahaan.

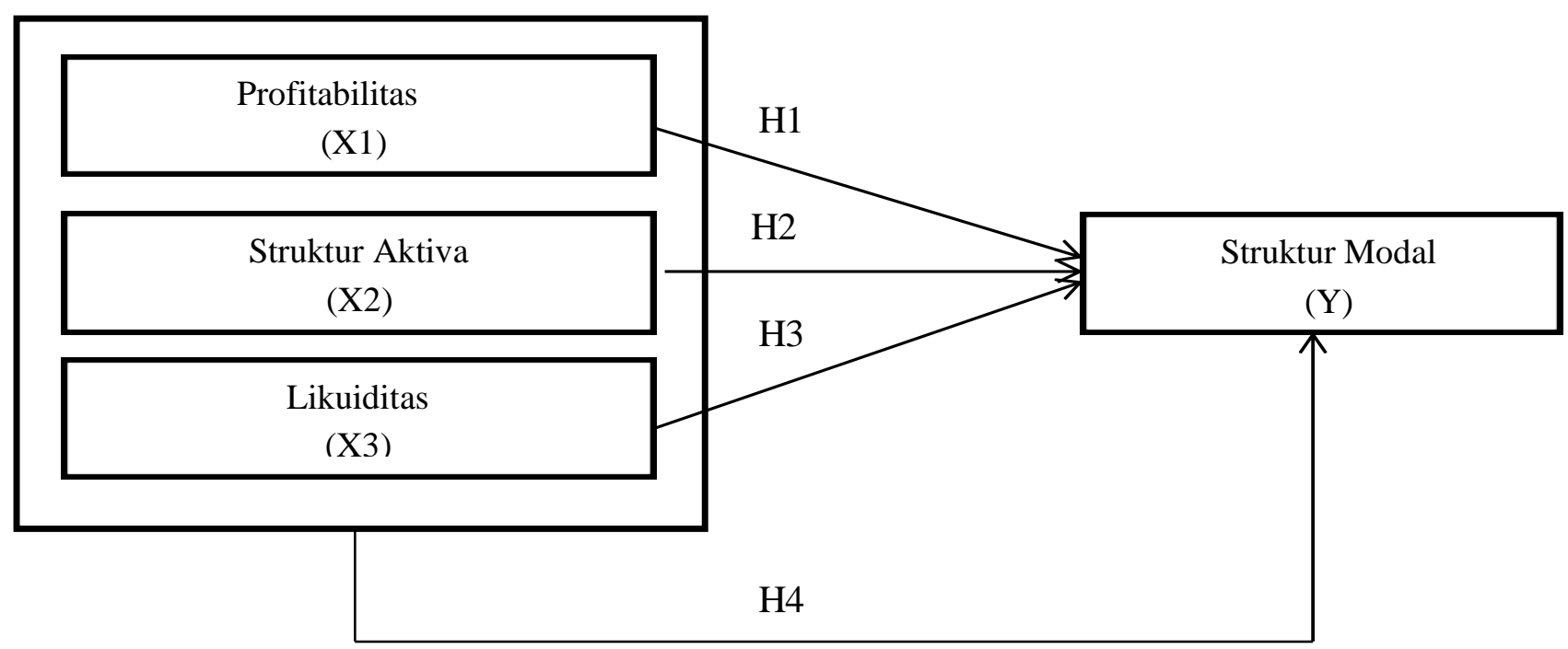

Gambar 1. Kerangka konseptual

\section{Hipotesis penelitian}

Berdasarkan kerangka penelitian dapat dirumuskan dengan rumusan hipotesis sebagai berikut:

H1 : Profitabilitas mempengaruhi terhadap Struktur Modal pada Perusahaan Makanan dan Minuman yang tercatat di BEI Periode 2014-2017.

H2 : Struktur Aktiva mempengaruhi terhadap Struktur Modal pada Perusahaan Makanan dan Minuman yang tercatat di BEI Periode 2014-2017.

H3 : Likuiditas mempengaruhi terhadap Struktur Modal pada Perusahaan Makanan dan Minuman yang tercatat di BEI Periode 2014-2017.

H4 : Profitabilitas, struktur Aktiva dan Likuiditas mempengaruhi terhadap Struktur modal pada Perusahaan Makanan dan Minuman yang tercatat di BEI Periode 2014- 2017 


\section{METODE}

\section{Jenis penelitian}

Penelitian ini berjenis deskriptif. Pendapat Sanusi (2012: 13), penelitian deskriptif ialah sebuah rencana penelitian yang diselenggarakan untuk mendeskripsikan terstruktur keterangan ilmiah yang bersumber dari subjek ataupun objek yang diteliti. Penelitiannya ini berpusat pada pernyataan fakta berurutan yang didapatkan sewaktu penelitian dilaksanakan.

\section{Sifat penelitian}

Penelitian bersifat kuantitatif. Pendapat Sugyono (2010:18), penelitian Kuantitatif bisa dilihat dari hubungan variabel dengan objek yang diperiksa lebih banyak kausalitasnya, sehingga dipenelitian ini terdapat variabel independent dan dependent. Dari variabel itulah maka terlihat besarnya pengaruh variabel bebas pada variabel terikatnya.

\section{Populasi}

Pendapat Sugyono (2010:115), Populasi ialah area penggeneralisasian yang meliputi objek dan subjek yang memiliki mutu dan ciri khas yang ditentukan sipeneliti agar bisa dipelajari dan juga bisa ditarik kesimpulannya.

Adapun populasinya yakni seluruh perusahaan Makanan dan Minuman yang tercatat di BEI tahun 2014-2017 sejumlah 18 perusahaan.

\section{Sampel}

Pengambilan sampelnya menggunakan purposive sampling. Pendapat Sugyono (2010: 122) Purposive sampling ialah teknik pengambilan sampel melalui suatu pertimbangan.

Syarat yang dipakai untuk memilih sampel penelitian ini adalah: 1).Perusahaan makanan dan minuman yang tercatat di BEI tahun 2014-2017. 2).Perusahaan makanan dan minuman yang tidak menerbitkan laporan keuangannya per 31 Desember dengan lengkap dan berurutan dan tahun 2014-2017. 3).Perusahaan makanan dan minuman yang mengalami kerugian selama tahun 2014-2017. Dari hasil penelitian berdasarkan kriteria diatas maka didapatkan sampel sebanyak 11 perusahaan Makanan dan Minuman. Kriteria sampel dapat diuraikan pada tabel II.1yakni:

Tabel 1 Sampel penelitian

\begin{tabular}{llc}
\hline No. & \multicolumn{1}{c}{ Kriteria } & Jumlah Sampel \\
\hline 1. & $\begin{array}{l}\text { Perusahaan makanan dan minuman yang tercatat di } \\
\text { BEI tahun 2014-2017. }\end{array}$ & 18 \\
2. $\quad \begin{array}{l}\text { Perusahaan makanan dan minuman yang tidak } \\
\text { menerbitkan laporan keuangannya per 31 Desember } \\
\text { dengan lengkap dan berurutan dan tahun 2014- 2017. }\end{array}$ & $(3)$ \\
3. & $\begin{array}{l}\text { Perusahaan makanan dan minuman yang menderita } \\
\text { kerugian pada tahun 2014-2017. }\end{array}$ \\
$\begin{array}{l}\text { Banyaknya sampel perusahaan } \\
\text { Banyaknya sampel yang lolos kriteria sebanyak } 9\end{array}$ \\
$\begin{array}{l}\text { perusahaan,maka observasi pengamatan secara } \\
\text { keseluruhan adalah 9x4 tahun. }\end{array}$
\end{tabular}




\section{Indentifikasi dan definisi operasional variabel penelitian}

Berdasarkan hasil penelitian Sugiyono (2009: 38), menyatakan bahwa variabel ialah sesuatu hal dalam bentuk apa pun yang ditentukan sipeneliti agar dipelajari untuk memperoleh penjelasan mengenai hal itu, maka diambil kesimpulan.

Adapun variabel penelitian ini yakni sebuah variabel terikat serta tiga variabel bebas.Variabel dependen dilambangkan oleh Y, yakni "Variabel yang mendapat pengaruh oleh variabel lainnnya". Variabel dependen yang dimaksud ialah:

\section{Struktur modal}

Struktur modal pada penelitian ini memakai LTDER yang melakukan perbandingan utang berjangka panjang perusahaan dengan keseluruhan modal perusahaan dari 20142017. Pendapat Wiagustini (2014: 88), Rasio Hutang Terhadap Ekuitas Jangka Panjang (DER) dinyatakan dalam persentase menggunakan rumus berikut :

Debt Equity Ratio $=\frac{\text { total } \text { hutang }}{\text { ekuitas }} \times 100 \%$

Variabel bebas dilambangkan dengan X. yakni "Variabel yang memengaruhi variabel lainnya". Adapun variabel bebasnya meliputi:

\section{Profitabilitas}

Profitabilitas pada penelitian ini bisa didapatkan melalui perbandingan keuntungan bersih dengan keseluruhan asset yang perusahaan miliki dari tahun 2014-2017. Rasio Profitabilitas yang dipakai ialah ROA. Pendapat dari Horne dan Wachowics (2012:182), nyatakan rumus ROA sebagai berikut :

$$
\mathrm{ROA}=\frac{\text { laba neto setelah pajak }}{\text { total aset }} \times 100 \%
$$

\section{Struktur aktiva}

Digunakan dengan menghitung perbandingan aktiva lancar dengan aktiva tetap pada perusahaan dari 2014-2017 di perusahaan makanan dan minuman di BEI. Menurut Riyanto (2011: 22), Struktur aktiva didapatkan dengan formula yakni :

$$
\text { Struktur Aktiva }=\frac{\text { aktiva tetap }}{\text { total aktiva }} \times 100 \%
$$

\section{Likuiditas}

Likuiditas didapatkan melaluip perbandingan aktiva lancar dengan kewajiban lancar dari 2014-2017 di perusahaan makanan dan minuman di BEI yang dinyatakan sebagai persentase. Menurut Sartono (2014:116), Current Ratio dihitung dengan formula yakni :

$$
\text { Current Ratio }=\frac{\text { aktiva lancar }}{\text { ekuitas untang lancar }} \times 100 \%
$$

\section{Uji asumsi klasik}

\section{Uji asumsi normalitas}

Tujuannya adalah untuk memahami apakah suatu distribusi data normal atau tidak. Menurut Sarjono dan Julianita (2011: 53), Uji normalitas yakni melakukan perbandingan antara data yang ada dan data yang terdistribusi normal yang dengan rerata serta standar 
deviasinya yang sama dengan data yang tersedia. Sehingga perlu diuji normalitasnya sebelum dilakukan uji regresi.

\section{Uji asumsi klasik multikolinieritas}

Tujuan dari pengujiannya agar memahami apakah korelasi antar variabel independen yang terjadi multikorelasi atau tidak. Menurut Sarjono dan Julianita (2011: 70), Multikorelasi yaitu suatu korelasi yang sangat tinggi atau rendah dalam hubungannya antara variabel independennya. Tes ini penting dilaksanakan bila banyaknya variabel independennya di atas satu.

\section{Uji asumsi klasik autokorelasi}

Pendapat Sarjono \& Julianita (2011: 80), Uji autokorelasi tujuannya adalah menguji apakah, pada pengujian hipotesis, terjadi kesalahan gangguan (disturbance term-ed) pada periode $t$ dengan (t-1). Apabila ada hubungan sehingga terdapat permasalahan autokorelasi.

\section{Uji asumsi klasik heteroskedastisitas}

Pendapat Sunyoto (2013: 90), Analisis uji asumsi heteroskedastisitas yaitu pengujian terkait varian residual yang sama atau tidak antar penelitiannya. apabila residual sama sehingga terdapat homoskedastisitas, bila berbeda yakni terdapat heteroskedastisitas

\section{Model analisis data penelitian}

Adapun teknik analisis datanya dengan analisis regresi linier berganda, yang modelnya dengan perhitungan yakni:

$$
\mathrm{Y}=\alpha+\beta 1 \mathrm{X} 1+\beta 2 \mathrm{X} 2+\beta 3 \mathrm{X} 3+\varepsilon
$$

Dengan :

$\begin{array}{ll}\mathrm{Y} & =\text { Struktur modal } \\ \mathrm{A} & =\text { Konstanta } \\ \beta 1,2,3,4 & =\text { Koefisien regresi setiap faktor } \\ \mathrm{X} 1 & =\text { Profitabilitas } \\ \mathrm{X} 2 & =\text { Struktur aktiva } \\ \mathrm{X} 3 & =\text { Likuiditas } \\ \varepsilon & =\text { Standar error } \\ \operatorname{taraf} \text { kepercayaan } & =95 \% \text { atau } \alpha=5 \%\end{array}$

\section{Koefisien determinasi (R2)}

Pendapat Ghozali (2013: 97), Koefisien determinasi R2 pada dasarnya menilai sejauh mana kemungkinan model untuk menjelaskan variasi variabel dependennya.

\section{Uji simultan (Uji F)}

Pendapat Ghozali (2013: 98), Pengujian F menjelaskan apakah seluruh variabel bebas yang dimasukkan pada model yang memiliki pengaruh bersamaan pada variabel terikatnya. Dalam pengujiannya memakai nilai signifikansi tingkat $5 \%$.

Kriteria pengujian hipotesis yaitu: $\mathrm{H} 0: \mathrm{bi}=0, \mathrm{i}=1,2$, dan 3 , berarti pengaruh profitabilitas,struktur aktiva, secara simultan tidak mempengaruhi pada struktur modal pada perusahaan makanan dan minuman tahun 2014-2017. HA: bi $\neq 0, \mathrm{i}=1,2$, dan 3 , berarti 
pengaruh profitabilitas,struktur aktiva, secara Simultan mempengaruhi pada struktur modal pada perusahaan makanan dan minuman tahun 2014- 2017. Dengan kualifikasi penentuan putusannya yakni: 1).Bila $F_{\text {hitung }}<F_{\text {tabeluntuk }} \alpha=5 \%$ sehingga $\mathrm{H}_{0}$ diterima dan $\mathrm{H}_{\mathrm{a}}$ ditolak. 2).Bila $F_{\text {hitung }}>F_{\text {tabeluntuk } \alpha}=5 \%$ sehingga $\mathrm{H}_{0}$ ditolak dan $\mathrm{H}_{\mathrm{a}}$ diterima

\section{Uji parsial (Uji t)}

Pendapat Ghozali (2013: 98), pengujian statistik T menyatakan sejauh mana pengaruhnya sebuah variabel bebas secara parsial dalam menjelaskan varians dari variabel terikatnya. Uji t dapat digunakan untuk melakukan perbandingan nilai signifikan $\mathrm{t}$ dengan $\alpha=0,05$. Pengujian ini digunakan melalui perbandingan $\mathrm{t}$ hitung dengan $\mathrm{t}$ tabel dengan ketetapan yakni: 1). $\mathrm{H} 0$ : $\mathrm{bi}=0, \mathrm{i}=1,2$, dan 3 , berarti pengaruh profitabilitas,struktur aktiva, secara parsial tidak mempengaruhi pada struktur modal pada perusahaan makanan dan minuman periode 2014-2017. 2).HA: bi $\neq 0, \mathrm{i}=1,2$, dan 3 , berarti pengaruh profitabilitas,struktur aktiva, secara parsial mempengaruhi pada struktur modal pada perusahaan makanan dan minuman tahun 2014-2017.

Dengan kualifikasi penentuan putusannya yakni: 1). Bila $t_{\text {hitung }}<\mathrm{t}_{\text {tabel }} u n t u k \alpha=5 \%$ sehingga $\mathrm{H} 0$ diterima dan HA ditolak. 2). Bila $t_{\text {hitung }}>t_{\text {tabel }}$ atau $-t_{\text {hitung }}<-t_{\text {tabel }}$ untuk $\alpha=5 \%$ sehingga $\mathrm{H} 0$ ditolak dan HA diterima

\section{HASIL DAN PEMBAHASAN}

\section{Statistik deskriptif}

Hasil sampel dalam penelitian ini, variabel independen yang diteliti adalah Profitabilitas, Struktur Aktiva, dan Likuiditas, sedangkan variabel bebasnya adalah Struktur Modal di perusahaan Makanan dan Minuman dengan total 36 data dalam setahun. Hasil statistik deskriptif bisa dilihat dibawah ini:

Tabel 2. Statistik deskriptif

\begin{tabular}{|c|c|c|c|c|c|c|}
\hline & & $\mathbf{N}$ & Minimum & Maximum & Mean & Std. Deviation \\
\hline ROI & & 36 & ,016 &, 527 & , 12583 &, 117454 \\
\hline FA & & 36 & 053 & 1,003 & ,55539 & ,224980 \\
\hline CR & & 36 &, 147 & 58,422 & 3,76017 & 9,549918 \\
\hline DER & & 36 &, 171 & 17,723 & 2,05107 & 3,916988 \\
\hline $\begin{array}{l}\text { Valid } \\
\text { (listwise) }\end{array}$ & $\mathrm{N}$ & 36 & & & & \\
\hline
\end{tabular}

Sumber: Data diolah, 2019

Variabel ROI nilai minimumnya 0,016 , nilai maksimumnya 0,527 , nilai rerata yakni 0,1583 dan standart deviasinya 0,117454 . Variabel FA nilai minimumnya 0,053 , nilai maksimumnya 1,0003, nilai rerata yakni 0,55539 dan standart deviasinya 0,224980 . Variabel CR dengan nilai minimum 0,147 , nilai maximum 58, 422, nilai rerata yakni 3,76017 dan standart deviasinya 9,549918. Variabel DER dengan nilai minimum 0,171, nilai maximum 17,72, nilai rerata yakni 2,05107 dan standart deviasinya 3,916988.

\section{Hasil uji asumsi klasik}

\section{Uji normalitas}

Uji normalitas bertujuan agar bisa mengetahui apakah model regresi variabel pengganggu atau variabel residual mempunyai distribusi normal dan untuk menguji 
model tersebut terdistribusi normal atau tidak menggunakan analisis grafis dengan statistik.

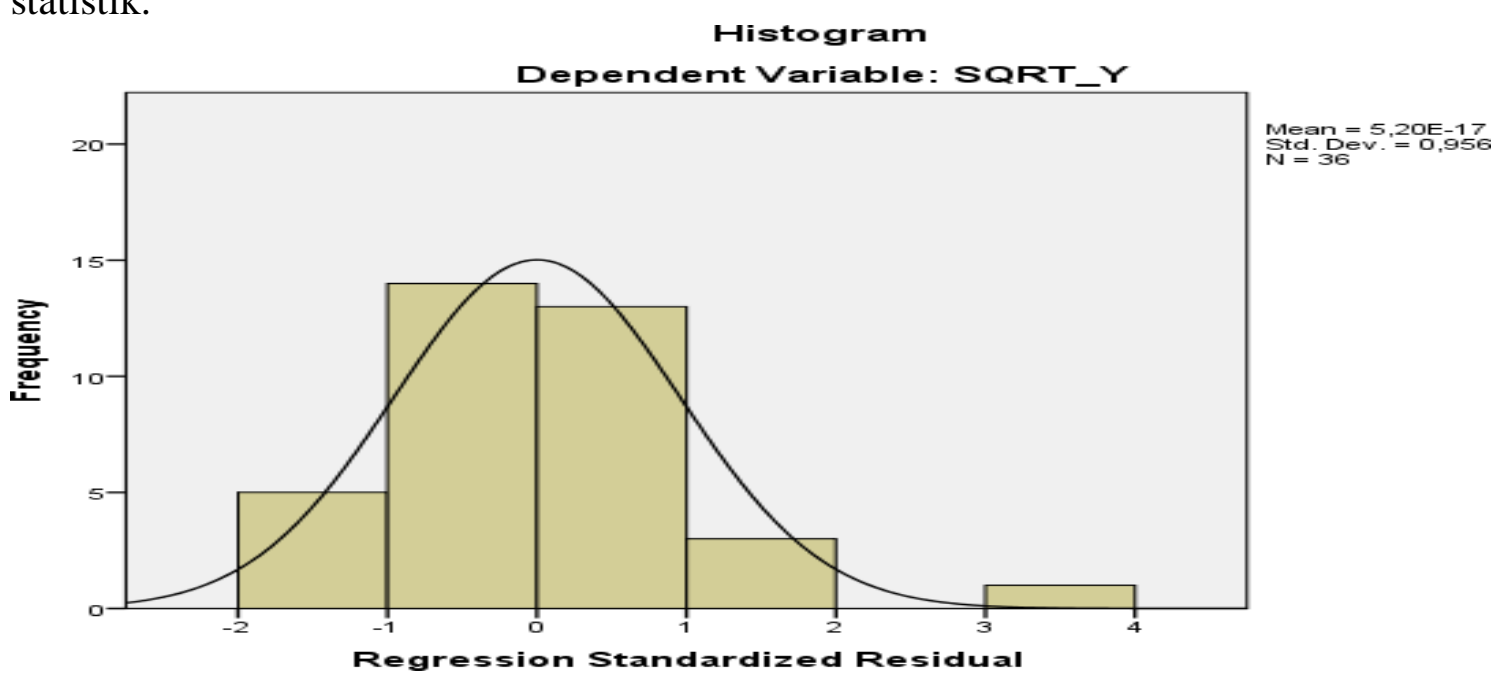

Sumber: Data diolah, 2019

Gambar 2. Hasil Uji Normalitas Grafik Histogram Sesudah Transformasi

Berdasarkan Gambar 2 setelah transformasi, memperlihatkan jika data memiliki distribusi normal. Hasil penelitian ini bisa diketahui dari grafik histogram hingga membentuk lonceng.

Berdasarkan Gambar 3, dapat dilihat bahwa grafik plot probabilitas normal setelah transformasi menunjukkan titik penyebaran dan menyertai arah garis diagonalnya dan penyebaranya disekitar garis diagonalnya, yang memperlihatkan jika model regresi sesuai dengan asumsi normalitasnya.

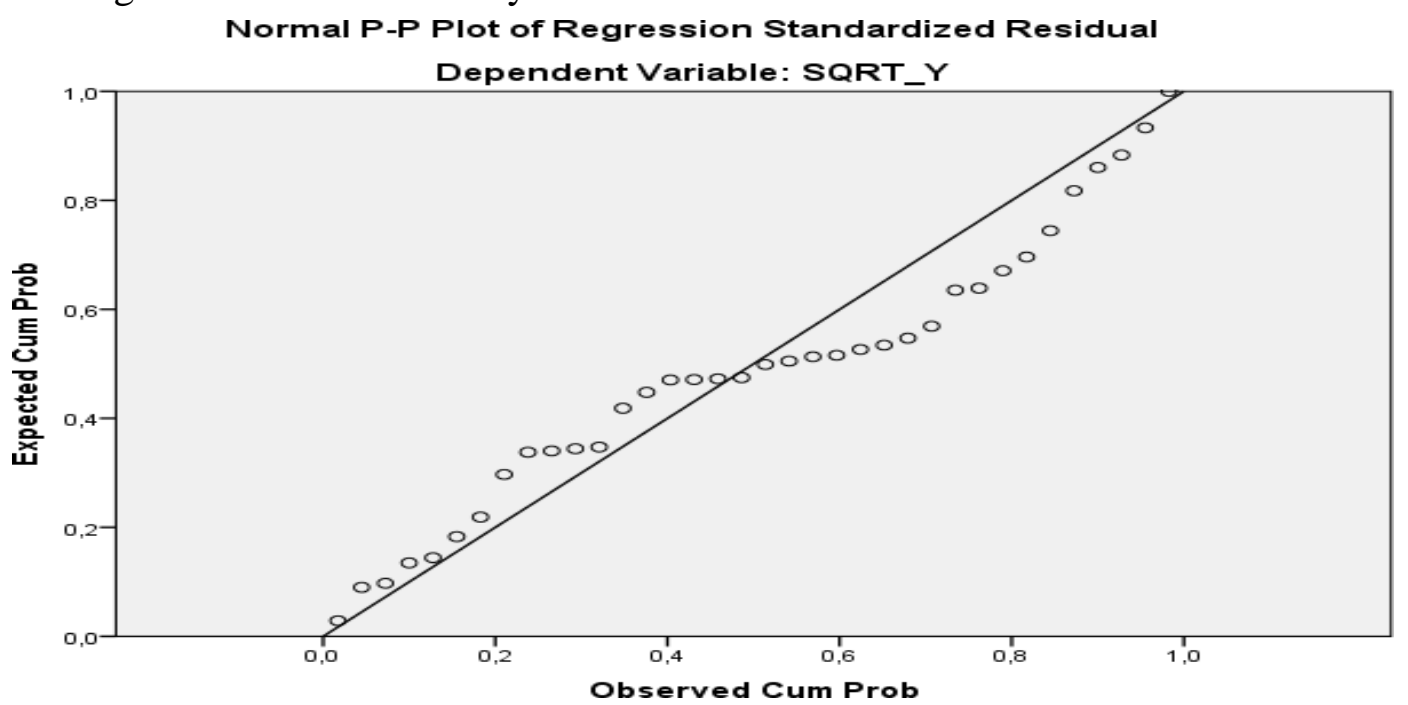

Sumber : Data diolah, 2019

Gambar 3: Probability Plot Sesudah Transformasi

\section{Analisis statistic}

Berdasarkan Tabel 3, hasil uji Kolmogorov-Smirnov (uji K-S) setelah transformasi adalah 0,901 dan nilai signifikannya yaitu 0,392 dengan nilai probabilitas $0,05(0,392>$ 0,05). Kesimpulan dari data bahwa HO diterima dan HA telah ditolak jadi data residual terdistribusi secara normal. 
Table 3. Hasil uji Kolmogrov-Smirmov setelah transformasi

\begin{tabular}{lll}
\hline Unstandardized Residual & & \\
\hline $\mathbf{N}$ & & $\mathbf{3 6}$ \\
\hline Normal Parameters & &, 0000000 \\
& Mean &, 67595142 \\
Most Extreme Differences & Std. Deviation &, 150 \\
& Absolute &, 150 \\
& Positive &,- 109 \\
Kolmogorov-Smirnov Z & Negative &, 901 \\
Asymp. Sig. (2-tailed) & &, 392 \\
Unstandardized Residual & & 36 \\
N & &, 0000000 \\
Normal Parameters &, 67595142 \\
& Mean &, 150 \\
Most Extreme Differences & Std. Deviation &, 150 \\
& Absolute &,- 109 \\
Kolmogorov-Smirnov Z & Positive &, 901 \\
Asymp. Sig. (2-tailed) & Negative &, 392 \\
\hline
\end{tabular}

a. Test distribution is Normal.

b. Calculated from data.

Sumber: Data diolah, 2019

\section{Uji multikolinieritas}

Uji Multikolinieritas dengan tujuan supaya mengetahui apakah model regresi terdapat korelasi antara variabel independennya. Multikorelasi dapat dilihat dari (1) nilai toleransi dan sebaliknya (2) variance inflation factor (VIF).

Tabel 3. Hasil uji multikolinieritas setelah transformasi

\begin{tabular}{llcc}
\hline \multirow{2}{*}{ Model } & \multicolumn{2}{c}{ Collinearity Statistics } \\
\cline { 3 - 4 } & (Constant) & Tolerance & VIF \\
\hline 1 & SQRT_X1 &, 923 & 1,083 \\
& SQRT_X2 &, 996 & 1,004 \\
& SQRT_X3 &, 927 & 1,079 \\
\hline
\end{tabular}

a.Dependent Variable: SQRT_Y8

Sumber : Data diolah, 2019

Berdasar Tabel 3 uji multikolinearitas terkait menyatakan nilai toleransinya 0,10 dan nilai VIF < 10 jadi bisa ditarik kesimpulan yakni hasil perhitungan nilai toleransi yakni tidak terdapat korelasi antara variabel independen bisa diberikan kesimpulan jika tetap terdistribusi normal.

\section{Uji autokorelasi}

Pengujian ini dengan tujuan untuk mengetahui apakah pada model regresinya terdapat hubungan antara kesalahan pengganggunya dalam periode $t$ dengan $t-1$ (sebelumnya). 
Tabel 4: Hasil uji autokorelasi sesudah transformasi

\begin{tabular}{|c|c|c|c|c|c|}
\hline Model & $\mathbf{R}$ & R Square & $\begin{array}{l}\text { Adjusted } \\
\text { Square }\end{array}$ & $\begin{array}{l}\text { R Std. Error of the } \\
\text { Estimate }\end{array}$ & Durbin-Watson \\
\hline 1 &, $562^{\mathrm{a}}$ & ,316 & ,252 & ,70693 & 1,848 \\
\hline
\end{tabular}

Pada Tabel 4, dapat dilihat hasil uji DW sebelum transformasi menunjukkan nilai DW sebesar 1,848 , nilai ini dapat dibandingkan dengan nilai tabel yang menggunakan nilai signifikan 5\% dengan jumlah sampel (n) 36 dan jumlah variabel independen 3 $(\mathrm{k}=3)$. Dari tabel DW mendapatkan nilai du (batas atas) sebesar 1,6539. Kriteria untuk bebas dari autokorelasi positif atau negatif adalah $\mathrm{du}<\mathrm{dw}<4-\mathrm{du}$. Dalam penelitian ini nilai DW 1,848 lebih besar dari nilai du sebesar 1,6539. Hasil pengujian ini adalah 1,6539 $\leq 1,848<2,3461$. Dimana nilai Durbin Watson lebih besar dari batas (du). Bisa disimpulkan bahwa model tersebut tidak terjadi autokorelasi positif atau negatif.

\section{Uji heterokedastisitas}

pengujiannya bertujuan untuk mengetahui apakah pada model regresinya terdapat ketaksamaan variasi dari residu antar penelitiannya. Model regresi terbaik adalah tidak terjadinya heteroskedastisitas.

Pada gambar 4 scatterplot setelah transformasi bahwa titik menyebar secara acak dan menyebar baik di atas maupun dibawah angka 0 pada sumbu Y. Dapat disimpulkan bahwa tidak terjadi heteroskedastisitas dalam model regresi.

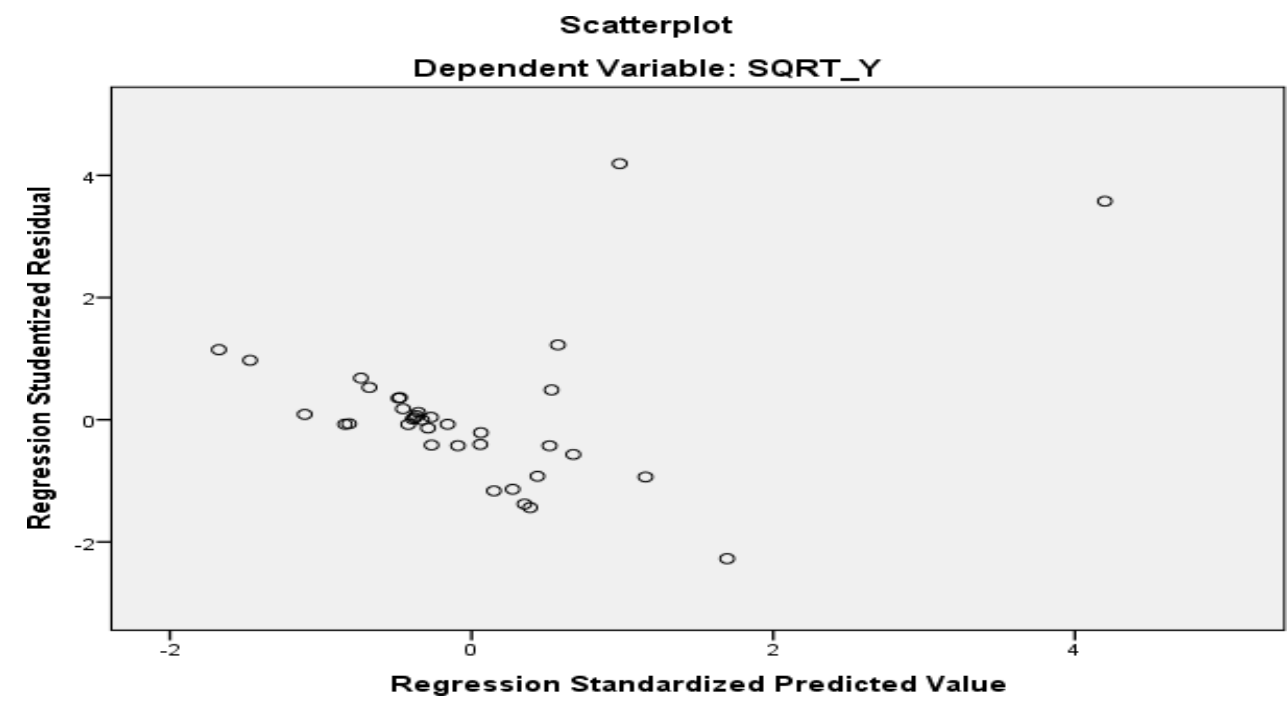

Sumber : Data diolah, 2019

Gambar 4. Grafik Scatterplot Sesudah Transformasi

Pada Tabel 5 menunjukkan pengujian glejser tersebut sesudah ditransformasikan dapat dilihat bahwa probabilitas atau taraf signifikansi variabel profitabilitas yakni 0,108 , struktur aktivanya ialah 0,043, dan likuiditas senilai 0,030. Dari hasil terkait, nilai variabel struktur aktiva dan likuiditas yang berada di bawah nilai tingkat signifikan 0,05 yaitu sebesar 0,043 dan 0,030 sehingga model regresi dikatakan mengalami sedikit heteroskedastisitas. 
Tabel 5. Hasil uji glejser setelah transformasi

\begin{tabular}{|c|c|c|c|c|c|c|}
\hline \multirow{2}{*}{\multicolumn{2}{|c|}{ Model }} & \multicolumn{2}{|c|}{$\begin{array}{l}\text { Unstandardized } \\
\text { Coefficients }\end{array}$} & \multirow{2}{*}{$\begin{array}{c}\text { Standardized } \\
\text { Coefficients } \\
\text { Beta } \\
\end{array}$} & \multirow[t]{2}{*}{$\mathbf{t}$} & \multirow[t]{2}{*}{ Sig. } \\
\hline & & B & Std. Error & & & \\
\hline \multirow[t]{4}{*}{1} & (Constant) & 1,477 & ,608 & & 2,430 & ,021 \\
\hline & SQRT_X1 & 1,430 & ,864 & ,252 & 1,656 & ,108 \\
\hline & SQRT_X2 & $-1,558$ & ,740 &,- 308 & $-2,104$ &, 043 \\
\hline & SQRT_X3 & ,241 & , 106 & ,346 & 2,279 &, 030 \\
\hline
\end{tabular}

a. Dependent Variable: SQRT_Y

Sumber : Data diolah, 2019

\section{Hasil analisis data penelitian}

\section{Model penelitian}

Penelitian ini menggunakan persamaan regresi linier berganda.

Tabel 6. Hasil regresi linier berganda

\begin{tabular}{lllllll}
\hline & & \multicolumn{2}{c}{$\begin{array}{c}\text { Unstandardized } \\
\text { Coefficients }\end{array}$} & $\begin{array}{c}\text { Standardized } \\
\text { Coefficients }\end{array}$ & t & Sig. \\
\cline { 2 - 5 } & B & Std. Error & Beta & & \\
\hline 1 & (Constant) & 1,477 &, 608 & & 2,430 &, 021 \\
& SQRT_X1 & 1,430 &, 864 &, 252 & 1,656 &, 108 \\
& SQRT_X2 & $-1,558$ &, 740 &,- 308 & $-2,104$ &, 043 \\
& SQRT_X3 &, 241 &, 106 &, 346 & 2,279 &, 030 \\
\hline
\end{tabular}

a. Dependent Variable: SQRT_Y

Sumber: Data diolah, 2019

Pada hasil Tabel 6 maka diperoleh persamaan regresi linier berganda hipotesis penelitian sebagai berikut :

\section{Struktur modal $=1,477+1,430 \mathrm{X}_{1}-1,558 \mathrm{X}_{2}+0,241 \mathrm{X}_{3}$}

Berdasarkan persamaan regresi bisa ditemukan bahwa hasil penelitian adalah sebagai berikut:Penelitian ini dapat dihasilkan nilai konstanta 1,477. Artinya bahwa profitabilitas, struktur aktiva, dan likuiditas dianggap konstan, maka struktur modal telah meningkat sebesar 1,477. Nilai koefisien regresi variabel profitabilitas $\left(\mathrm{X}_{1}\right)$ sebesar 1,430. Dapat diartikan bahwa setiap peningkatan 1 unit profitabilitas akan meningkat sebesar $0,143 \%$ dengan asumsi variabel lainnya konstan. Nilai koefisien variabel struktur aktiva $\left(\mathrm{X}_{2}\right)$ sebesar $-1,558$. Hal tersebut membuktikan bahwa setiap penurunan 1 unit struktur aktiva akan menghasilkan penurunan sebesar $0,1558 \%$ dengan asumsi variabel lainnya konstan. Nilai koefisien variabel likuiditas $\left(\mathrm{X}_{3}\right)$ sebesar 0,241. Bisa diartikan bahwa setiap 1 unit peningkatan rasio lancar akan mennyebabkan peningkatan sebesar $0,0241 \%$ dengan asumsi variabel lainnya konstan.

\section{Koefisien determinasi $\left(\mathbf{R}^{\mathbf{2}}\right)$}

Uji koefisien determinasi (adjusted $R$ square) memiliki tujuan untuk melihat sejauh mana kemampuan model didalam menerangkan variasi variabel dependennya. 
Tabel 7. Hasil koefisien determinasi

\begin{tabular}{|c|c|c|c|}
\hline Model & R Square & $\begin{array}{l}\text { Adjusted R } \\
\text { Square }\end{array}$ & $\begin{array}{c}\text { Std. Error of the } \\
\text { Estimate }\end{array}$ \\
\hline 1 & ,562 $\quad, 316$ &, 252 & ,70693 \\
\hline
\end{tabular}

Pada Tabel 7, dapat diketahui dari hasil nilai adjusted $R$ square yang disesuaikan sebesar 0,252 atau $25,2 \%$. Berarti hal ini menyatakan bahwa variabel dependen yaitu struktur modal, bisa dijelaskan oleh variasi dari tiga variabel independen, yaitu profitabilitas, struktur aktiva dan likuiditas sebesar $25,2 \%$, sedangkan sisanya sebesar $74,8 \%$ dijelaskan oleh variabel lain yang tidak terdapat dalam penelitian ini.

\section{Pengujian hipotesis secara parsial (Uji t)}

Uji t memliki tujuan didalam melihat sejauh mana pengaruhnya sebuah variabel independen mempengaruhi variabel dependennya.

Tabel 8. Hasil uji t coefficients ${ }^{\mathrm{a}}$

\begin{tabular}{lllllll}
\hline \multirow{2}{*}{ Model } & \multicolumn{2}{c}{$\begin{array}{c}\text { Unstandardized } \\
\text { Coefficients }\end{array}$} & $\begin{array}{c}\text { Standardized } \\
\text { Coefficients }\end{array}$ & t & Sig. \\
\cline { 3 - 5 } & B & Std. Error & Beta & & \\
\hline 1 & (Constant) & 1,477 &, 608 & & 2,430 &, 021 \\
& SQRT_X1 & 1,430 &, 864 &, 252 & 1,656 &, 108 \\
& SQRT_X2 & $-1,558$ &, 740 &,- 308 & $-2,104$ &, 043 \\
& SQRT_X3 &, 241 &, 106 &, 346 & 2,279 &, 030 \\
\hline
\end{tabular}

a. Dependent Variable: SQRT_Y

Sumber : Data diolah, 2019

Dalam penelitian ini, angka t tabel adalah sebesar 2,02809. Jadi, hasil uji parsial yaitu: 1).Variabel profitabilitas (X1) dengan angka t hitung 1,656 dimana nilai t tabel adalah 2,02809. Dari hasil ini maka bisa terlihat dari $\mathrm{t}$ hitung $<\mathrm{t}$ tabel pada taraf signifikannya $0,108>0.05$, maka simpulannya H0 diterima dan HA ditolak artinya variabel profitabilitas tidak mempengaruhi pada struktur modal perusahaan makanan dan minuman yang tercatat di BEI Tahun 2014-2017. 2).Variabel struktur aktiva (X2) memiliki nilai $-2,104<\mathrm{t}$ tabel 2,02809 pada taraf signifikannya $0,043<0,05$, sehingga simpulannya H0 ditolak dan HA diterima yang berarti variabel struktur aktiva mempengaruhi negatif dan signifikan pada struktur modal perusahaan makanan dan minuman yang tercatat di BEI Tahun 2014-2017. 4).Variabel likuiditas (X3) memiliki nilai 2,279 > t tabel 2,02809 pada taraf signifikannya $0,030<0.05$. sehingga simpulannya H0 ditolak dan HA diterima artinya variabel likuiditas mempengaruhi positif dan signifikan pada struktur modal perusahaan makanan dan minuman yang tercatat di BEI Tahun 2015-2017.

\section{Pengujian hipotesis secara simultan (Uji F)}

Uji $\mathrm{F}$ bertujuan untuk memeriksa bagaimanakah pengaruhnya antar variabel independen secara bersamaan pada variabel dependennya. 
Tabel 9 Hasil uji F

ANOVA $^{b}$

\begin{tabular}{lllllll}
\hline \multicolumn{1}{c}{ Model } & $\begin{array}{c}\text { Sum of } \\
\text { Squares }\end{array}$ & Df & Mean Square & F & Sig. \\
\hline 1 & Regression & 7,387 & 3 & 2,462 & 4,927 &, $006^{\mathrm{a}}$ \\
Residual & 15,992 & 32 &, 500 & & \\
Total & 23,379 & 35 & & & \\
\hline
\end{tabular}

a.Predictors: (Constant), SQRT_X3, SQRT_X2,SQRT_X1

b.Dependent Variable: SQRT_Y

Sumber : Data diolah, 2019

Pada Tabel 9 bisa diamati berdasar nilai $\mathrm{F}$ hitung yakni 4,927 dengan tingkat signifikansinya $0,006<0,05$. Selanjutnya dilakukan perbandingan dengan $\mathrm{F}$ tabel pada taraf kepercayaannya 95\%. Pada Tabel F untuk $\alpha=0,05$ nilai $\mathrm{F}$ diperoleh tabel $=2,87$. Dikarenakan $\mathrm{F}$ hitung $>\mathrm{F}$ tabel dengan taraf signifikansi kurang dari 0,05, sehingga membuktikan yakni variabel profitabilitas, struktur aktiva dan likuditas secara bersamaan mempengaruhi secara signifikan pada struktur modal di perusahaan makanan dan minuman yang tercatat di BEI Tahun 2014-2017. Kesimpulan dari perhitungan diatas yakni H0 ditolak dan HA diterima.

\section{Pengaruh profitabilitas terhadap struktur modal}

Berdasar analisisnya menyatakan profitabilitas tidak mempengaruhi struktur modalnya. Berarti bisa dinyatakan bahwa perusahaan tidak mempertimbangkan jumlah profitabilitas yang didapatkan dalam menetapkan struktur permodalan dikarenakan perusahaan sudah menentukan struktur modal sesuai jumlah pengembalian dan bea permodalan yang dikeluarkan dikarenakan pemanfaatan utang untuk menunjang operasi perusahaannya.

Sependapat dengan penelitian oleh Vina Ratna dn Saifudin (2012), yang menemukan yakni profitabilitas tidak mempengaruhi pada struktur permodalannya. Sedangkan Nadia Puspawardhani (2014), yang menemukan Profitabilitas mempengaruhi positif dan signifikan pada struktur modalnya.

\section{Pengaruh struktur aktiva terhadap struktur modal}

Berdasar analisisnya menjelaskan variabel struktur aktiva secara parsial mempengaruhi negatif dan signifikan pada struktur modalnya, berarti makin tinggi struktur aktiva yang diperoleh maka makin rendah struktur permodalannya.

Sependapat dengan penelitian oleh Huson Joher, Mohd Ali dan Nazrul (2006), menjelaskan yakni struktur aktiva mempengaruhi negative dan signifikan pada struktur modalnya sementara Putra dan Diantini (2015) yang menyatakan struktur aktiva mempengaruhi positif pada struktur modalnya.

\section{Pengaruh likuiditas terhadap struktur modal}

Berdasar analisisnya menyatakan likuiditas mempengaruhi positif dan signifikan pada struktur modalnya, artinya jika likuiditas tinggi sehingga struktur modalnya tinggi secara signifikan. Sehingga Perusahaan yang dinilai positif di mata kreditur, apabila tingkat likuiditas perusahaan tersebut tinggi. Perusahaan dengan tingkat likuiditasnya 
tinggi berkemungkinan lebih mudah memperoleh sumber dana melalui hutang.

Sependapat dengan penelitian oleh Ardiyana dan Ardiana (2014), dapat dinyatakan yakni likuiditas mempengaruhi positif dan signifkan pada struktur modalnya sementara menurut Seksak (2011), mengatakan likuiditas mempengaruhi negative dan signifikan pada modalnya.

\section{KESIMPULAN DAN SARAN}

\section{Kesimpulan}

Variabel profitabilitas secara individual tidak mempengaruhi siginifikan pada struktur modal perusahaan makanan dan minuman yang tercatat di BEI tahun 2014-2017. Variabel struktur aktiva secara individual mempengaruhi negative dan signifikan pada stuktur modal perusahaan makanan dan minuman yang tercatat di BEI tahun 2014-2017. Variabel likuiditas mempengaruhi positif dan signifikan terhadap struktur modal pada perusahaan makanan dan minuman yang tercatat di BEI Tahun 2015-2017.Variabel profitabilitas, struktur aktiva serta lkuiditas secara serentak mempengaruhi positif dan signifikan pada struktur modal pada perusahaan makanan dan minuman yang tercatat di BEI Tahun 20142017.

Nilai profitabilitas simultan (uji F) terlihat dari hasil nilai adjusted $R$ square senilai 0,252 atau $25,2 \%$. Hal itu menyatakan variabel dependen adalah struktur modal bisa dinyatakan dalam variasi dari tiga variabel independennya, yakni profitabilitas, struktur aktiva dan likuiditas senilai $25,2 \%$, sementara sisanya $74,8 \%$ dijelaskan oleh variabel lainnya yang tidak terdapat pada penelitian ini.

\section{Saran}

Bagi perusahaan, seharusnya diperhatikan variabel profitabilitas, struktur aktiva, dan likuiditas dalam menentukan struktur modal nya , terutama profitabilitas dikarenakan variabel terkait sangat mempengaruhi signifikan pada struktur modalnya. Penentuan struktur modal ialah sesuatu yang utama pada perusahaan dikarenakan manfaat struktur modal akan mempengaruhi keuangan perusahaan.

Bagi investor, harus melihat tingkat profitabilitas perusahaan karena investor akan menginvestasikan modalnya di perusahaan yang memiliki tingkat profitabilitas tinggi dan struktur modal yang jelas agar mendapatkan laba dari penanaman modal yang dilakukan.

Bagi peneliti selanjutnya, peneliti yang memeriksa variabel sejenis disarankan unuk meningkatkan jumlah variabel independen yang diinginkan dan meningkatkan jumlah tahun atau perusahaan yang berbeda untuk mendapatkan informasi yang lebih baik lagi.

\section{DAFTAR PUSTAKA}

Fahmi.(2014). Analisis Kinerja Keuangan. Alfabeta: Bandung

Hery.(2013). Teori Akuntansi Suatu Pengantar. Fakultas Ekonomi Universitas Indonesia: Jakarta

Infantri \& Suwitho. (2015). Pengaruh Likuiditas, Profitabilitas, Ukuran Perusahaan terhadap Struktur Modal pada Perusahaan Otomotif yang Terdaftar di BEI. Jurnal Ilmu dan Riset Manajemen, 4(7), 1-15.)

Kamaludin \& Rini Indriani.(2012). Manajemen Keuangan. Ed. Revisi, CV. Mandar Maju: Bandung

Kasmir. (2012). Analisis Laporan Keuangan. Cetakan Kelima. PT. Raja Grafindo 
Persada: Jakarta:

Made Yunitri Deviani, Luh Komang Sudjarni.(2018).Pengaruh Tingkat Pertumbuhan Struktur Aktiva, Profitabilitas, dan Likuiditas terhadap Struktur Modal Perusahaan Pertambangan di BEI. E-Jurnal Manajemen Unud, 7(3), 1222-1254. Mulyawan. (2015). Manajemen Keuangan. CC Pustaka Setia: Bandung :

Riski Ayu Pratiwi Batubara,dkk. (2017).Pengaruh Struktur Aktiva, Ukuran Perusahaan, dan Profitabilitas terhadap Struktur Modal. Jurnal Administrasi Bisnis. 50(4), 1-9 Sarjono, H., \& Julianita, W. (2011). SPSS vs LISREL Sebuah Pengantar, Aplikasi untuk Riset. Salemba Empat: Jakarta

Sudana.(2015). Teori dan Praktek Manajemen Keuangan Perusahaan Edisi 2. Erlangga. Sunyoto, D. (2013). Metodologi Penelitian Akuntansi. PT Refika Aditama Anggota Ikapi. Bandung:

Van Horne \& John. (2012). Prinsip-Prinsip Manajemen Keuangan. Salemba Empat: Jakarta

Weston \& Copeland.(2010). Manajemen Keuangan. Binarupa Aksara: Jakarta Wiagustini, Ni Luh Putu.(2014). Dasar-dasar Manajemen Keuangan . Cetakan Pertama. Udayana Universitas Press: Denpasar: 